\title{
High abundances of small copepods early developmental stages and nauplii strengthen the perception of a non-dormant Arctic winter
}

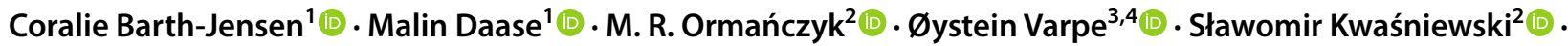 \\ Camilla Svensen ${ }^{1}$ (D)
}

Received: 14 September 2021 / Revised: 30 January 2022 / Accepted: 31 January 2022 / Published online: 15 February 2022

(c) The Author(s) 2022

\begin{abstract}
The traditional view is that the Arctic polar night is a quiescent period for marine life, but recent reports of high levels of feeding and reproduction in both pelagic and benthic taxa have challenged this. We examined the zooplankton community present in Svalbard fjords, coastal waters, and the shelf break north of Svalbard, during the polar night. We focused on the population structure of abundant copepods (Calanus finmarchicus, Calanus glacialis, Metridia longa, Oithona similis, Pseudocalanus spp., Microcalanus spp., and Microsetella norvegica) sampled using 64- $\mu \mathrm{m}$ mesh nets. Numerically, copepod nauplii ( $\geq 50 \%$ ) and the young developmental stages of small copepods ( $<2 \mathrm{~mm}$ prosome length as adult) dominated the samples. Three main patterns were identified: (1) large Calanus spp. were predominantly older copepodids CIV-CV, while (2) the small harpacticoid M. norvegica were adults. (3) For other species, all copepodid stages were present. Older copepodids and adults dominated populations of $O$. similis, Pseudocalanus spp. and M. longa. In Microcalanus spp., high proportion of young copepodids CI-CIII indicated active winter recruitment. We discuss the notion of winter as a developing and reproductive period for small copepods in light of observed age structures, presence of nauplii, and previous knowledge about the species. Lower predation risks during winter may, in part, explain why this season could be beneficial as a period for development. Winter may be a key season for development of small, omnivorous copepods in the Arctic, whereas large copepods such as Calanus spp. seems to be reliant on spring and summer for reproduction and development.
\end{abstract}

Keywords Polar night $\cdot$ Copepod stage structure $\cdot$ Population composition $\cdot$ Svalbard $\cdot$ Fjords $\cdot$ Overwintering strategies

\section{Introduction}

Polar environments are characterized by extremes in light conditions, ranging from periods of midnight sun (polar day) to periods when the sun does not rise above the horizon (polar night). The duration of the polar night varies with latitude (Cohen et al. 2020). Zooplankton species have adapted to this period of low light intensities and low

Coralie Barth-Jensen

coralie.barth-jensen@uit.no

1 Faculty of Biosciences, Fisheries and Economics, UiT The Arctic University of Norway, 9037 Troms $\varnothing$, Norway

2 Institute of Oceanology, Polish Academy of Sciences, Sopot, Poland

3 Norwegian Institute for Nature Research, 5006 Bergen, Norway

4 Department of Biological Sciences, University of Bergen, 5020 Bergen, Norway food concentrations by developing strategies reducing their metabolic expenditure (see Berge et al. 2020 and references within). In the Arctic, omnivorous copepod species, such as the small cyclopoid Oithona similis, remain active during winter although activity may be reduced compared to other seasons (Berge et al. 2020), and feeding continues often accompanied with a change in prey spectrum (Grønvik and Hopkins 1984; Norrbin 1991; Dvoretsky and Dvoretsky 2009a, 2015a). Primarily herbivorous zooplankton such as Calanus spp., undertake extensive vertical seasonal migrations, decrease their metabolism while in deep water during winter and survive on accumulated energy reserves (Conover 1988; Atkinson 1998; Varpe 2012). Relatively large and mainly herbivorous copepods of the genus Calanus hold a key position in the energy transfer from primary producers to higher trophic levels in the Arctic ecosystem (Søreide et al. 2008). Their low activity during winter may have given rise to the view that the Arctic winter is a season of dormancy (Berge et al. 2015a, 2020). However, recent 
observations of high biological activities, such as feeding, growth, and reproduction, during the polar night (Berge et al. 2009, 2015a; Kraft et al. 2013; Båtnes et al. 2015; Vader et al. 2015; Webster et al. 2015) are challenging this traditional view that the polar night is a period of dormancy (Hirche and Kosobokova 2011; Darnis et al. 2012; Berge et al. 2015b).

There are far fewer studies of ecological processes in zooplankton during the polar night than at other times of the year (but see, e.g., Hirche and Kosobokova 2011; Kosobokova and Hirche 2016; Daase et al. 2018; Berge et al. 2020). Studies of zooplankton communities during the Arctic polar night have usually been carried out using acoustic instruments (e.g., Berge et al. 2009; Darnis et al. 2017 ) or nets with mesh size $\geq 180 \mu \mathrm{m}$ (e.g., Hirche and Kosobokova 2011; Daase et al. 2014, 2018; Webster et al. 2015; Kosobokova and Hirche 2016). These gears detect large zooplankton, but small-sized taxa and young small life stages are underrepresented or go undetected (Nichols and Thompson 1991; Nielsen and Andersen 2002; Svensen et al. 2019). As a result, knowledge about the small species and life-stage compositions of zooplankton communities in the Arctic during winter is limited (but see Ussing 1938; Digby 1954; Lischka and Hagen 2005, 2016; Arendt et al. 2013; Grenvald et al. 2016).

Small copepod taxa ( $\leq 2 \mathrm{~mm}$ adult prosome length, Roura et al. 2018) and copepod nauplii are widely distributed throughout the Arctic and often numerically dominant in fjords (Madsen et al. 2008; Arendt et al. 2013; Ormańczyk et al. 2017), shallow seas and deeper basins (Apollonio 2013; Dvoretsky and Dvoretsky 2014, 2015b; Balazy et al. 2018). Small copepods, mainly omnivores, are often described as being winter-active, because they feed (Castellani et al. 2007) and reproduce during this period (Lischka and Hagen 2005, 2016). Reproduction is generally lower during winter than during periods of high food availability because most small copepods are income breeders; i.e.they depend on an exogenous food supply to fuel reproduction (Varpe et al. 2009). Their feeding on marine snow and microzooplankton (Svensen and Kiørboe 2000; Calbet and Saiz 2005; Koski et al. 2007) impacts carbon flux; small copepods may be a major contributor to the retention of carbon in surface waters (Svensen et al. 2018; Mayor et al. 2020), and they are probably an important food source for heterotrophic predators in surface waters during winter (Falkenhaug 1991; Saito and Kiørboe 2001; Arendt et al. 2013; Grigor et al. 2014). Therefore, small copepods may have a key role in the Arctic marine ecosystem during winter, and information about their population dynamics could increase our understanding about their ecological role in pelagic waters in the Arctic polar night.

Here, we describe the structure of the mesozooplankton community in the western Barents Sea and Svalbard waters $\left(70^{\circ}\right.$ to $81^{\circ} \mathrm{N}$ ) during the polar night (January), focusing on the abundant small copepod taxa $(O$. similis, Pseudocalanus spp., Microcalanus spp., and Microsetella norvegica), the large copepod taxa (Metridia longa, Calanus finmarchicus, and Calanus glacialis), and the most abundant meroplankton. We hypothesize that the population structure of each of these seven taxa will reflect their reproductive strategy: high abundance of young copepodid stages (CI) in January would indicate winter recruitment and likely reproduction of these species, whereas a predominance of older copepodids (IV to adult) would indicate the lack of thereof. This study aims to broaden our knowledge about the life-history of small copepod species in the Arctic.

\section{Materials and methods}

\section{Study area}

Sampling was conducted onboard R/V Helmer Hanssen during the Polar Night cruise 2017 (PNC17), 6th to 17th January 2017 in the waters of the western Barents Sea and Svalbard archipelago. The area is influenced by the West Spitsbergen Current (WSC), a continuation of the North Atlantic Current that transports Atlantic waters across the western entrance of the Barents Sea and along the western coast of Svalbard (Cottier et al. 2005). The WSC branches North of Svalbard with one branch transporting Atlantic water eastwards along the northern shelf of Svalbard toward the Arctic Ocean, and the other transporting water westward, toward Fram Strait and east coast of Greenland. Sampling was conducted at six oceanic stations and seven stations in three fjords over an $11^{\circ}$ latitudinal range (Fig. 1a, Table 1).

Two oceanic stations (TB1 and TB2) were located in the western Barents Sea (Fig. 1a), within the main path of the Atlantic water flow (Cottier et al. 2005). The other four oceanic stations were located on the shelf (NS1, NS4, and NS10) and off-shelf (NS6) north of Svalbard. NS4 and NS6 were deep stations $(>1000 \mathrm{~m})$, whereas NS1 and NS10 were shallower, $208 \mathrm{~m}$ and $343 \mathrm{~m}$ respectively (Table 1). Bellsund, at the opening of Van Mijenfjorden (station VMF9), and Krossfjorden (stations KF1, KF2, and KF3) were located on the west coast of Svalbard and were affected by the inflow of Atlantic water from the WSC as well as colder Arctic water from the Coastal Current (Cottier et al. 2005). Rijpfjorden (stations R3, R3b, and R4) was located on the northern coast of Nordaustlandet and was mainly influenced by Arctic water, but could seasonally experience an inflow of Atlantic water (Wallace et al. 2010).

\section{Water sampling and analyses}

Environmental salinity, temperature, and fluorescence data were collected using a ship-board conductivity, 


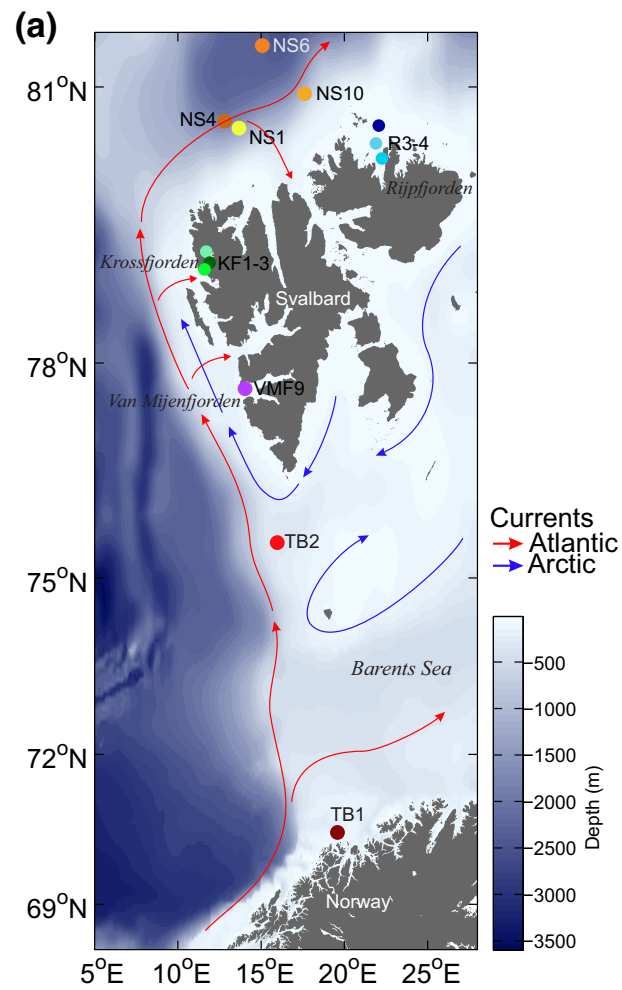

Fig. 1 a Map of the study area with sampling station positions and names. Bathymetry and main ocean currents are given for reference. b Plot of the temperature and salinity in the water column (down to 138-400 m, see Table 1 for station depths) at each of the 13 stations.

temperature and depth profiler (SBE911plus, SeaBird Electronics). Water samples were collected at depths of 5, $15,50,100,200$, and $300 \mathrm{~m}$ using 8 -L Niskin bottles on a CTD rosette. No water sampling was performed at VMF9 and NS4. The water from each depth was divided into 3 aliquots of $500 \mathrm{~mL}$ filtered through $\mathrm{GF} / \mathrm{F}$ filters $(0.7 \mu \mathrm{m})$ for total chlorophyll $a(\mathrm{Chl} a)$, and 3 aliquots of $500 \mathrm{~mL}$ filtered through pre-combusted $\mathrm{GF} / \mathrm{F}$ filters for particulate organic carbon (POC). Filters were then stored at $-20^{\circ} \mathrm{C}$ until analysis. For $\mathrm{Chl} a$ extraction, the filters were placed in $5 \mathrm{~mL}$ methanol and extracted overnight at $4{ }^{\circ} \mathrm{C}$ in darkness (modified from Strickland and Parsons 1972). Chl $a$ fluorescence was then analyzed in a fluorometer (10-AU, Turner Designs, California, USA). Prior to analysis, the POC filters were dried and fumed with concentrated $\mathrm{HCl}$ to remove inorganic carbon. Filters were analyzed using a CHN Lab Leeman 440 elemental analyzer. Measured values of POC for blanks (unused pre-combusted GF/F filters) were subtracted from those with filtered samples.
Light gray lines show isopycnals. The different water mass boundaries are defined by rectangles, following Cottier et al. (2005), and the blue lines represent pycnoclines

\section{Zooplankton sampling and identification}

Zooplankton was sampled using vertically stratified net hauls with a multiple opening/closing net (MultiNet type Midi, Hydro-Bios, Germany, mouth opening $0.25 \mathrm{~m}^{2}$, $64-\mu \mathrm{m}$ mesh size, towing speed $0.4 \mathrm{~m} \mathrm{~s}^{-1}$ ). The four depth strata sampled were 3-50 m, 50-100 m, 100-200 m, and 200-400 $\mathrm{m}$, or to $10 \mathrm{~m}$ above the bottom at stations shallower than $400 \mathrm{~m}$. A $64-\mu \mathrm{m}$ mesh WP-2 net (Hydro-Bios, Germany, opening $0.25 \mathrm{~m}^{2}$ ) was used for the $0-50 \mathrm{~m}$ sampling at station TB2 due to a tear in the MultiNet net bag. A technical error resulted in only the upper $100 \mathrm{~m}$ being sampled at station KF1. We focus on comparing the zooplankton community in the surface layer from 0 to $100 \mathrm{~m}$ and the deeper layer from $100 \mathrm{~m}$ to bottom (at $138-372 \mathrm{~m}$ ) or $400 \mathrm{~m}$, and assume that copepods present in the upper $100 \mathrm{~m}$ are not in diapause.

Immediately after collection the samples were fixed in hexamethylenetetramine-buffered formaldehyde in seawater solution at $4 \%$ final concentration. The samples were later analyzed under a stereomicroscope (Olympus SZX7). 


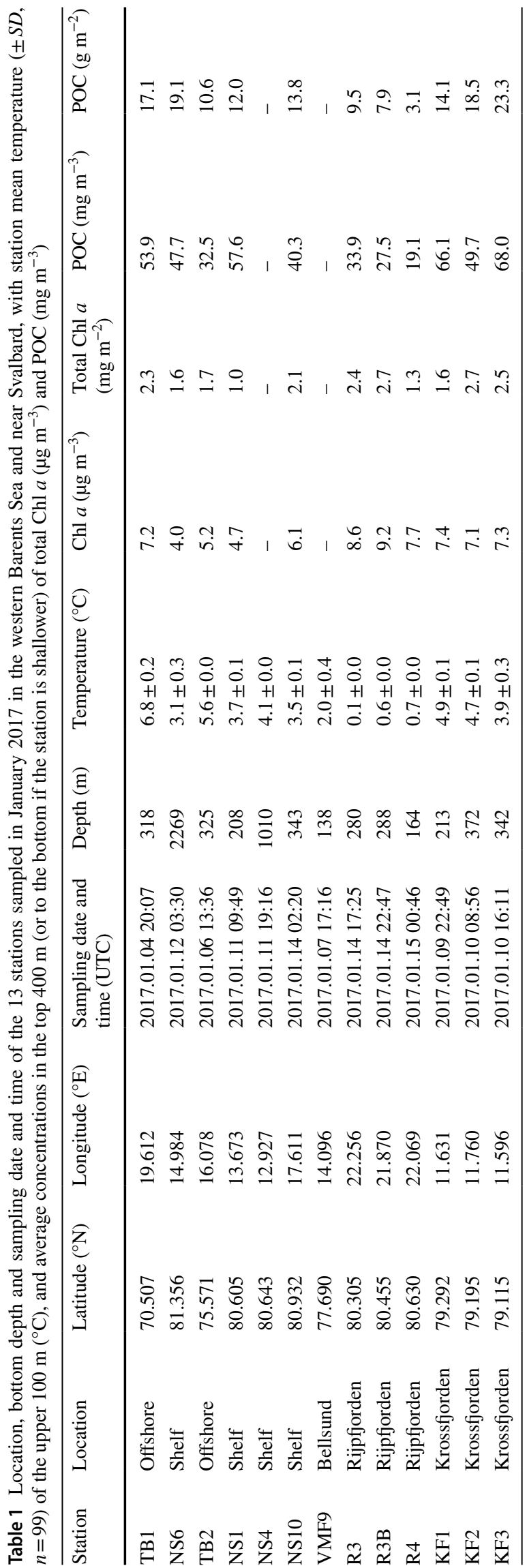

Organisms with total length $>5 \mathrm{~mm}$ were sorted from the sample, identified and counted. Then aliquots were taken with a $2-\mathrm{mL}$ pipette with the tip cut at $5-\mathrm{mm}$ diameter to allow collection of mesozooplankton. The number of aliquots and subsamples analyzed was chosen so that at least 300 individuals were counted in each sample. The remainder of the sample was screened for rare species. Specimens were identified to the lowest taxonomic level possible and classified as holoplankton or meroplankton.

For copepods, a detailed analysis of copepodid stage composition was performed for Calanus spp., O. similis, M. norvegica, Pseudocalanus spp., M. longa, and Microcalanus spp. The CI to CIII stages were not differentiated for Microcalanus spp. at station TB1, and for $O$. similis and $M$. norvegica at all stations. Younger stages (CI to CIII) classified as Microcalanus spp. probably included young copepodids of Paracalanus spp., Clausocalanus spp., and Ctenocalanus spp. (particularly at the stations TB1 and TB2 in the western Barents Sea), because it is difficult to distinguish these species via visual identification. The CI to CIII stages of M. longa and M. lucens were not differentiated, and were designated M. longa. The three Calanus species were differentiated on the basis of size (Kwasniewski et al. 2003); this involves some uncertainty because prosome lengths of species of the genus can overlap (Gabrielsen et al. 2012; Choquet et al. 2018). Copepod nauplii were determined to order (Calanoida, Cyclopoida, and Harpacticoida). Copepod species were differentiated as either "small copepods" (prosome length $<2 \mathrm{~mm}$, Roura et al. 2018) or "large copepods" (prosome length $\geq 2 \mathrm{~mm}$; Online Resource 1) according to female body size.

\section{Ovigerous females of Oithona similis}

Prosome length and clutch size of egg-carrying $O$. similis were measured at stations KF2 and R3 to assess reproductive status. The number of egg-carrying females of other species was too low to allow assessment. Copepods were collected using a WP-2 net $(90-\mu \mathrm{m}$ mesh, non-filtering cod-end) towed from $100 \mathrm{~m}$ to the surface. Three net hauls were taken and the samples were transferred to a $20-\mathrm{L}$ bucket filled with surface seawater. The samples were screened for egg-carrying $O$. similis females under a stereomicroscope in a cold room $\left(+2{ }^{\circ} \mathrm{C}\right)$. The prosome length of females was measured $(n=59)$, and the number of egg sacs and the total number of eggs per female (i.e., the clutch size) were counted by dissecting the egg sacs with a fine needle. Due to rough sea, only approximately half of the sample was screened and the presence of ovigerous females was therefore only qualitatively assessed. 


\section{Data analysis}

To compare zooplankton communities between stations, a non-metric cluster analysis was performed with complete linkage and chi-square distances for Bray-Curtis similarities calculated for depth integrated species abundances (ind. $\mathrm{m}^{-2}$ ). The calculations of the Bray-Curtis dissimilarity index did not consider the demographic structure of a given species (abundance of copepodid stages), but only the total number of the species at the station. No data transformation was carried out because the aim was to focus on the most common species in the community comparison. Correspondence analysis (CA) was carried out to clarify which species drove the variability in community structure. Integrated abundances (ind. $\mathrm{m}^{-2}$ ) of individual species were calculated for each station. The data set was simplified to the 9 most common copepod species, "other copepods", and other taxonomic groups (i.e., chaetognaths, appendicularians, ctenophores, hydrozoans, pteropods, euphausiids, other crustaceans, and meroplankton). Calanoida, Cyclopoida, and Harpacticoida nauplii were included separately. The cluster analysis and $\mathrm{CA}$ used the $\mathrm{R}$ version 1.3.959 package vegan version 2.5-6 (Oksanen et al. 2019).

Integrated total Chl $a\left(\mathrm{mg} \mathrm{Chl} a \mathrm{~m}^{-2}\right)$ and POC $\left(\mathrm{g} \mathrm{C} \mathrm{m}^{-2}\right)$ were calculated for the upper $400 \mathrm{~m}$ (or less depending on station depth), assuming the depths at which the samples were collected represented the midpoint of each sampling interval. The total biomass $\left(\mathrm{mg} \mathrm{C} \mathrm{m}^{-2}\right)$ of the most common species of copepods was calculated by summing stagespecific biomasses for a species. Stage-specific biomasses were estimated by multiplying the stage-specific integrated abundance (ind. $\mathrm{m}^{-2}$ ) by the individual stage-specific carbon weights of copepodids $\left(\mu \mathrm{g} \mathrm{C}\right.$ ind $\left.^{-1}\right)$, as published by Svensen et al. (2019). As most of the nauplii were in the size range of $O$. similis nauplii, the carbon weight of $O$. similis nauplii was applied to all nauplii, irrespective of taxonomic order. This may have led to some inaccuracy in nauplii biomass estimations.

Following recommendations from Greenacre (2016), means were reported with the dispersion interval, i.e., the estimated 0.025 and 0.975 quantiles which encompass $95 \%$ of the observations, and the number of observations $(n)$ in parenthesis. The only exception was for surface temperature $(0-100 \mathrm{~m})$ and the clutch size of $O$. similis, which were given as means \pm standard deviation $(S D)$.

\section{Results}

\section{Hydrography and environmental conditions}

Atlantic Water $\left(\mathrm{T}>3{ }^{\circ} \mathrm{C}, \mathrm{S}>34.65\right)$ dominated the southern stations TB1 and TB2 (Fig. 1b). At TB2, the water column was homogeneous, but a halocline was present at TB1 between 100 and $150 \mathrm{~m}$ (Fig. 1b). Waters of Atlantic origin (Transformed Atlantic Water $\left(1<\mathrm{T}<3{ }^{\circ} \mathrm{C}, \mathrm{S}>34.65\right)$ and Atlantic Water) prevailed in the upper $400 \mathrm{~m}$ at the stations north of Svalbard (NS1, NS4, NS6, and NS10).

Krossfjorden (KF1, KF2, and KF3) and Bellsund (VMF9) were characterized by Intermediate Water and Transformed Atlantic Water (Fig. 1b). Water masses were warmer in Krossfjorden (between 3 and $\left.5{ }^{\circ} \mathrm{C}\right)$ than in Bellsund $\left(2{ }^{\circ} \mathrm{C}\right.$, Fig. 1b; Table 1). Rijpforden (R3, R3b, and R4) was the only location with Arctic Water $\left(\mathrm{T} \leq 1{ }^{\circ} \mathrm{C}, 34.3 \leq \mathrm{S} \leq 34.8\right)$.

All offshore and fjord stations were ice free, with low concentrations of Chl $a\left(\leq 9 \mu \mathrm{g} \mathrm{m}^{-3}\right)$ and POC $\left(\leq 68 \mathrm{mg} \mathrm{m}^{-3}\right.$, Table 1).

\section{Zooplankton community composition}

A total of 75 taxa and taxonomic groups were identified (Barth-Jensen et al. 2022). Copepods dominated the zooplankton community both in terms of abundance and biomass. Within the copepod community, copepod nauplii dominated numerically (30 to 3253 ind. $\mathrm{m}^{-3}$ per water layer, Fig. 2a, c), but they contributed little in terms of biomass (3 to $123 \mu \mathrm{g} \mathrm{C} \mathrm{m}^{-3}$, Table 2). Cyclopoid nauplii were abundant while harpacticoid nauplii were rare (Fig. 2b, d). The calanoid nauplii were mostly small, but a few large ones $(\sim 470 \mu \mathrm{m})$ were present. The copepod community was numerically dominated by small copepods (18 to 1724 ind. $\mathrm{m}^{-3}$, Fig. 2a, c), with biomass amounting to 19 to $1089 \mu \mathrm{g}$ $\mathrm{C} \mathrm{m}^{-3}$ (Table 2). Eighteen small copepod taxa were present, with $O$. similis (6 to 1155 ind. $\mathrm{m}^{-3}$, mean $=17 \%$ of the zooplankton community, dispersion interval $=[8,26] \%, n=13$ ) and Microcalanus spp. ( 7 to 370 ind. $\mathrm{m}^{-3}$, mean $=12 \%$ of the zooplankton community, dispersion interval $=[7,18] \%$, $n=13$, Fig. 3 ) being the most abundant. In contrast, the 14 large copepod taxa identified were present in relatively low abundances (between 3 and 83 ind. $\mathrm{m}^{-3}$, Fig. 2a, c), which accounted in average for only $3 \%$ of the total zooplankton abundance across stations (dispersion interval $=[1,8] \%$, $n=13$, Fig. $2 \mathrm{~b}, \mathrm{~d}$ ). The three most abundant large copepod species were $C$. finmarchicus ( 3 to 61 ind. $\mathrm{m}^{-3}$ ), C. glacialis ( 0 to 24 ind. $\mathrm{m}^{-3}$ ), and $M$. longa ( 0 to 13 ind. $\mathrm{m}^{-3}$, Fig. 3 ), and they also dominated in terms of biomass $(\geq 1038 \mu \mathrm{g} \mathrm{C}$ $\mathrm{m}^{-3}$, Table 2). However, the use of a $64-\mu \mathrm{m}$ mesh net may underestimate the abundance of large copepods.

Other zooplankton were rare, with the abundance of non-copepod holoplankton ranging from 2 to 719 ind. $\mathrm{m}^{-3}$ and meroplankton from 0.3 to 96 ind. $\mathrm{m}^{-3}$ (Fig. 2a, c). The pteropods Clione limacina and Limacina spp. were common (Fig. 4a), with a particularly high abundance of Limacina veliger at TB1 (up to 668 ind. $\mathrm{m}^{-3}$, most likely Limacina retroversa) where they contributed $28 \%$ to the zooplankton community in terms of abundance (Fig. 2b). 
Fig. 2 a, c Cumulated abundance (ind. $\mathrm{m}^{-3}$ ) and $\mathbf{b}, \mathbf{d}$ relative abundance of the zooplankton community in the study area in January 2017. Depth intervals sampled: 0 to $100 \mathrm{~m}$ (a, b), and $100 \mathrm{~m}$ to bottom $(\max .400 \mathrm{~m})(\mathbf{c}, \mathbf{d})$. Only upper $100 \mathrm{~m}$ sampled at KF1. Copepod nauplii abundance is plotted independently of the large and small copepod groups, and is marked by open triangles
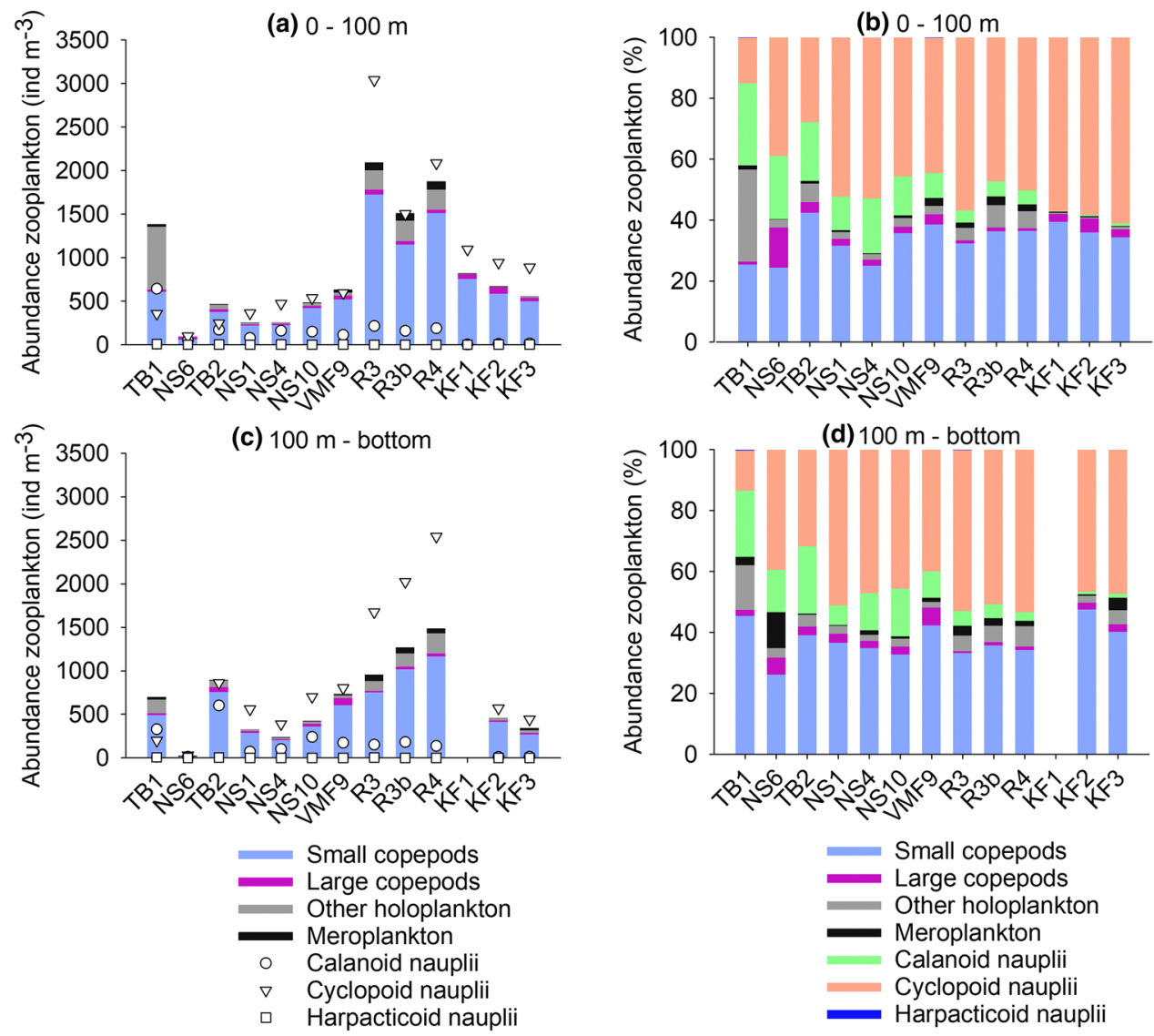

Table 2 Integrated biomass $\left(\mu \mathrm{g} \mathrm{m}^{-3}\right.$ ) of the most abundant copepods in the zooplankton community.

\begin{tabular}{|c|c|c|c|c|c|c|c|c|c|c|c|c|c|}
\hline Species & TB1 & NS6 & TB2 & NS1 & NS4 & NS10 & VMF9 & R3 & $\mathrm{R} 3 \mathrm{~b}$ & $\mathrm{R} 4$ & KF1 & KF2 & KF3 \\
\hline Calanus finmarchicus & 362 & 376 & 897 & 253 & 471 & 580 & 356 & 218 & 455 & 252 & 338 & 661 & 404 \\
\hline Calanus glacialis & 126 & 32 & 828 & 66 & 45 & 344 & 347 & 323 & 504 & 561 & 246 & 990 & 459 \\
\hline Metridia longa & 49 & 8 & 77 & 18 & 65 & 81 & 54 & 52 & 37 & 28 & 22 & 71 & 56 \\
\hline Sum of large copepods & 536 & 415 & 1802 & 337 & 581 & 1005 & 757 & 592 & 997 & 842 & 607 & 1722 & 919 \\
\hline Pseudocalanus spp. & 25 & 0 & 10 & 2 & 3 & 4 & 38 & 49 & 50 & 31 & 5 & 68 & 43 \\
\hline Microcalanus spp. & 42 & 6 & 97 & 14 & 31 & 56 & 29 & 47 & 65 & 55 & 17 & 59 & 38 \\
\hline Microsetella norvegica & 8 & 0 & 2 & 0 & 0 & 1 & 1 & 3 & 4 & 2 & 0 & 2 & 1 \\
\hline Oithona similis & 42 & 2 & 35 & 9 & 14 & 25 & 9 & 66 & 100 & 68 & 28 & 41 & 32 \\
\hline Sum of small copepods & 116 & 8 & 144 & 25 & 48 & 85 & 77 & 165 & 219 & 156 & 50 & 171 & 114 \\
\hline Copepod nauplii & 10 & 1 & 15 & 5 & 10 & 14 & 5 & 19 & 25 & 18 & 6 & 11 & 9 \\
\hline
\end{tabular}

The sums of large and small copepods take into account only present species.

For meroplankton, polychaete larvae were common mostly in fjords $\left(\leq 16 \times 10^{3}\right.$ ind. $\left.\mathrm{m}^{-2}\right)$, and bivalve veliger were observed at all stations $\left(\leq 7 \times 10^{3}\right.$ ind. $\mathrm{m}^{-2}$, Fig. $\left.4 \mathrm{~b}\right)$.

Stations that had similar temperature and salinity (T-S) profiles (Fig. 1b) had highest similarity in zooplankton community composition (Fig. 5a). Two main cluster groups were identified, based on mesozooplankton species abundance, one consisting of fjord stations, and the other of offshore stations. Two stations, TB1 and NS6 were not part of either of the groups (Fig. 5). TB1 differed from all other stations primarily due to an unusually high abundance of Limacina veliger and the highest abundance of the warmer water copepods Paracalanus spp., Clausocalanus spp., and Ctenocalanus spp. (Fig. 5b; Barth-Jensen et al. 2022). Moreover, TB1 was the only station where the abundance of calanoid nauplii was higher than that of cyclopoid nauplii, representing $63 \%$ of the total nauplii abundance (Fig. 3). NS6 was characterized by a low total zooplankton abundance (Fig. 2a, 

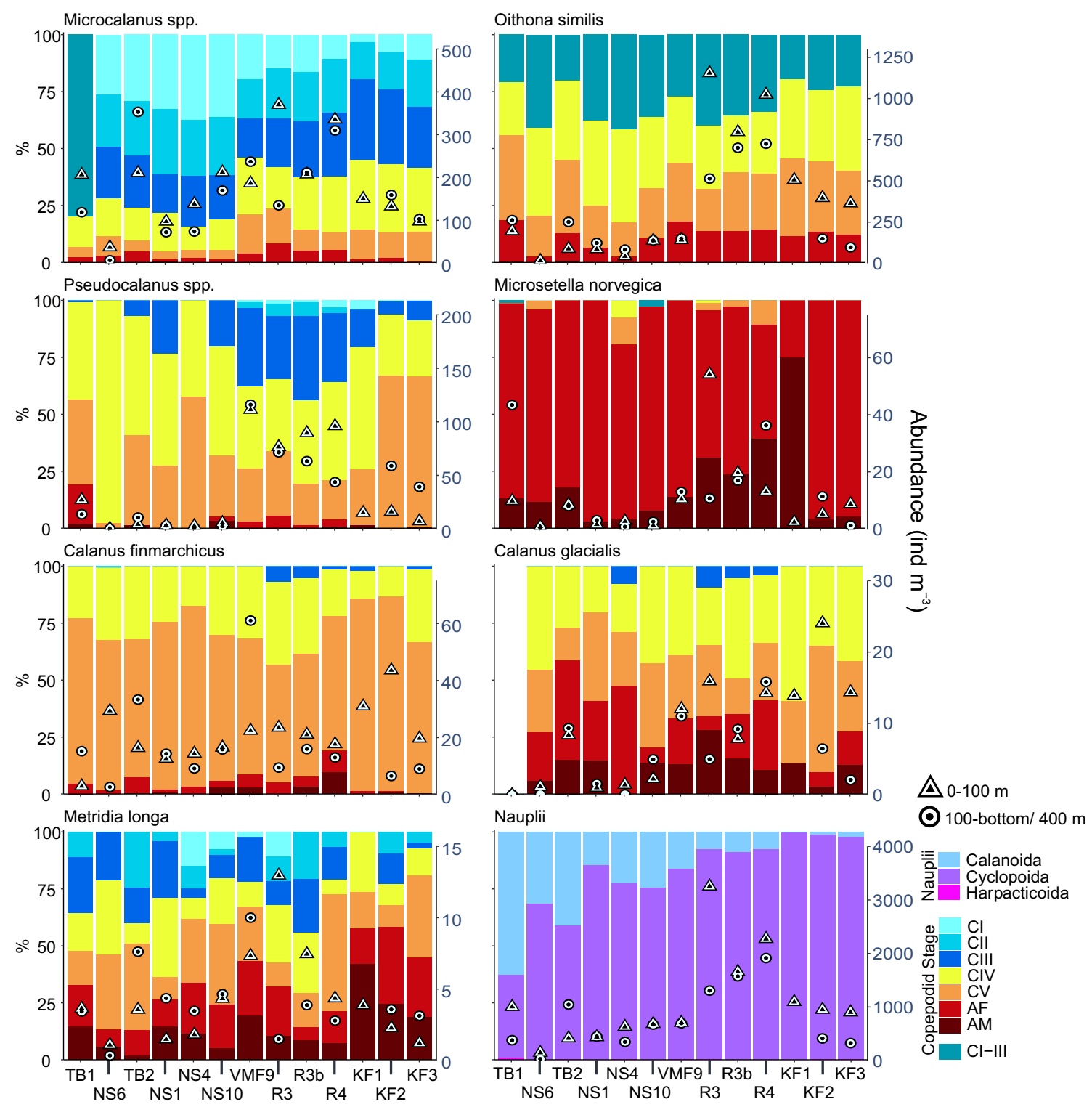

Fig. 3 Stage-specific composition (color bars, relative abundance, left axis) and total abundance of copepodids CI to adults (ind. $\mathrm{m}^{-3}$, right axis) above $100 \mathrm{~m}$ (dotted line) or below $100 \mathrm{~m}$ (black line) of seven

abundant copepod taxa and copepod nauplii (Calanoida, Cyclopoida, Harpacticoida) in the study area in January 2017. Note different scales on the right $y$-axis

c), but zooplankton composition was similar to that of the other offshore stations (Fig. 5b).

The zooplankton communities at offshore stations were characterized by high proportions of calanoid nauplii (mean $=33 \%$ of the total nauplii community, dispersion interval $=[16,60] \%, n=7$, Fig. 3), Oncaeidae (mostly Triconia borealis), and Microcalanus spp. (Fig. 5b), but abundances were usually lower than in fjords (Fig. 3). Community compositions at the shelf stations north of Svalbard (NS1, NS4, NS10) were more similar to each other than to the community at TB2, which had higher abundances of large copepods (C. finmarchicus, C. glacialis, $M$. longa) and Microcalanus spp. (Fig. 3).
In contrast to the offshore stations, zooplankton communities in the fjords were characterized by relatively high abundances of $O$. similis, Pseudocalanus spp. and cyclopoid nauplii (mean $=94 \%$ of the total nauplii population, dispersion interval $=[85,100] \%, n=7$, Figs. 3 and 5b). Within the fjord cluster, stations from the same fjord showed high similarity in zooplankton community composition. Krossfjorden had the highest proportions of cyclopoid nauplii recorded in the study (Figs. 3 and 5b). Rijpfjorden was characterized by high abundances of $O$. similis, $M$. norvegica, Pseudocalanus spp., and nauplii (Fig. 3). The zooplankton community in Bellsund was generally similar to that of the other fjord stations (Fig. 5a), with a generally high abundance of small 

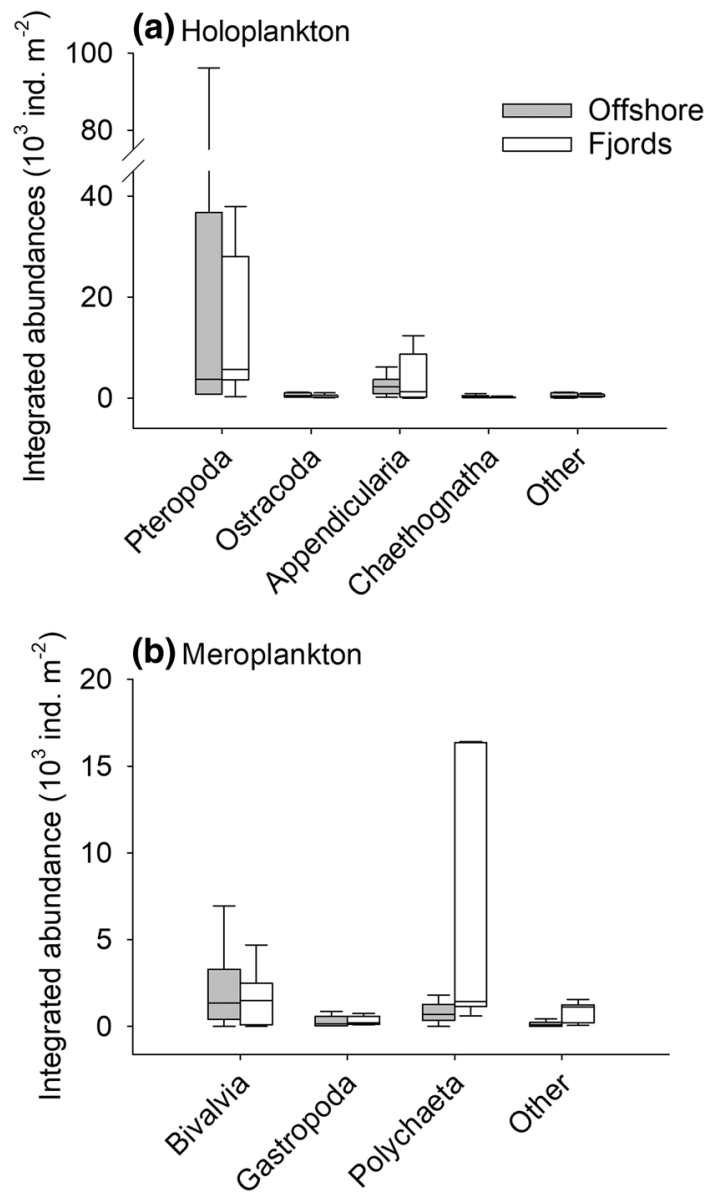

Fig. 4 Boxplot of the integrated abundance (ind. $\mathrm{m}^{-2}$ ) of a non-copepod holoplankton taxa and $\mathbf{b}$ meroplankton at offshore stations in the Barens Sea and near Svalbard $(n=6)$ and in Svalbard fjords $(n=7)$ in January 2017. The top and bottom boundaries of the box indicate the 25th and 75th percentile, and the black line within the box shows the median. Whiskers indicate the 10th and 90th percentiles

copepods, but the proportion of calanoid nauplii was comparable to that of offshore stations (Fig. 3).

\section{Population structure of the most abundant small and large copepod species}

Small copepods were usually more abundant in the upper $100 \mathrm{~m}$ than deeper, irrespective of the sampling station (Fig. 3), with no specific differences in the depth distribution of each species between stations. Microcalanus spp. populations were dominated by young copepodids (CI to CIII), although in higher proportions offshore (mean $=78 \%$, dispersion interval $=[72,84] \%, n=6)$ than at fjord stations (mean $=58 \%$, dispersion interval $=[54,63] \%, n=7$, Fig. 3 ). Males were scarce, resulting in a high female:male ratio (maximum of 236).

Oithona similis populations were characterized by the presence of all developmental stages, with younger copepodids CI to CIII making up more than a quarter of a population (Fig. 3). Female abundance varied widely between stations $\left(0.2\right.$ to 158 ind. $\left.\mathrm{m}^{-3}\right)$ and males were rare $\left(0\right.$ to 6 ind. $\left.\mathrm{m}^{-3}\right)$, resulting in a high female:male ratio $($ mean $=41$, dispersion interval $=[10,94], n=7)$. The mean prosome length of $O$. similis females was $444 \mu \mathrm{m}$ (dispersion interval $=[364,563] \mu \mathrm{m}, n=59)$. Ovigerous females were present in very low numbers, and had an average clutch size of 5 eggs ( $S D=2$ eggs, $n=12$ ). Only four females carried 2 egg sacs. One female carried an egg sac that showed signs of recent hatching: a torn sac with eggs at an advanced stage of development (nauplii nearly formed).

For Pseudocalanus, copepodids CIV and CV were the most common developmental stages (Fig. 3), and young copepodids CI and CII were only found in the fjords (Fig. 3). Males were rare and only a few Pseudocalanus spp. females with egg sacs were observed by chance in the live samples. The mean female:male ratio was 1.8 (dispersion inter$\mathrm{val}=[0.0,7.4], n=7)$.

Populations of $M$. norvegica were almost entirely adults, with only a few copepodids CI-CV being recorded (Fig. 3). The female:male ratio was in average 10.6 (dispersion interval $=[0.6,30.1], n=13)$, with a higher contribution of females at offshore stations (mean $=86 \%$, dispersion inter$\mathrm{val}=[77,96] \%, n=6)$ than in the fjords (mean $=70 \%$, dispersion interval $=[29,96] \%, n=7$, Fig. 3). Abundances of $M$. norvegica males were sometimes high locally (maximum 5.7 ind. $\mathrm{m}^{-3}$ at station TB1), and they contributed in average $27 \%$ to populations in the fjords (dispersion interval $=[4$, $70] \%, n=7)$.

The depth distribution of $C$. finmarchicus differed between southern and northern locations. C. finmarchicus was mostly located below $100 \mathrm{~m}$ at southern Barents Sea stations (TB1, TB2) and in Bellsund (VMF9), while in Krossfjorden, Rijpfjorden and at the shelf stations north of Svalbard, C. finmarchicus was most abundant in the upper $100 \mathrm{~m}$ (Fig. 3). There was no such pattern in the depth distributions of $C$. glacialis and M. longa (Fig. 3). Older copepodids $\mathrm{CIV}$ and $\mathrm{CV}$ were the most commonly encountered stage of both C. finmarchicus and C. glacialis. For C. glacialis, adult females $($ mean $=20 \%$, dispersion interval $=[2,46] \%$, $n=12)$ and males (mean $=12 \%$, dispersion interval $=[1$, $25] \%, n=12$ ) were also common (Fig. 3). The female:male ratio was relatively balanced for $C$. glacialis (mean $=1.6$, dispersion interval $=[0.1,3.4], n=11)$, but higher female abundance in $C$. finmarchicus gave a mean ratio of 2.9 (dispersion interval $=[0.2,12.7], n=8)$. Younger Calanus spp. copepodids CIII were observed in low numbers, mostly in the fjords, and CI and CII were usually absent (Fig. 3). For M. longa, older copepodids CIV and CV and adults dominated the populations, but younger copepodids CI-CIII were also present $($ mean $=25 \%$, dispersion interval $=[2 \%, 43 \%]$, $n=13$; Fig. 3 ). Adult male and female $M$. longa had similar 
Fig. 5 a Cluster dendrogram (based on chi-square distances) and $\mathbf{b}$ Biplot of correspondence analysis based on the integrated abundance (ind. $\mathrm{m}^{-2}$ ) of all species at each of the 13 stations in and near Svalbard sampled in January (circles in b). Only the 12 taxonomic groups (red triangles) that contributed most to the variance are shown in $\mathbf{b}$. The color coding refers to the clustering of stations
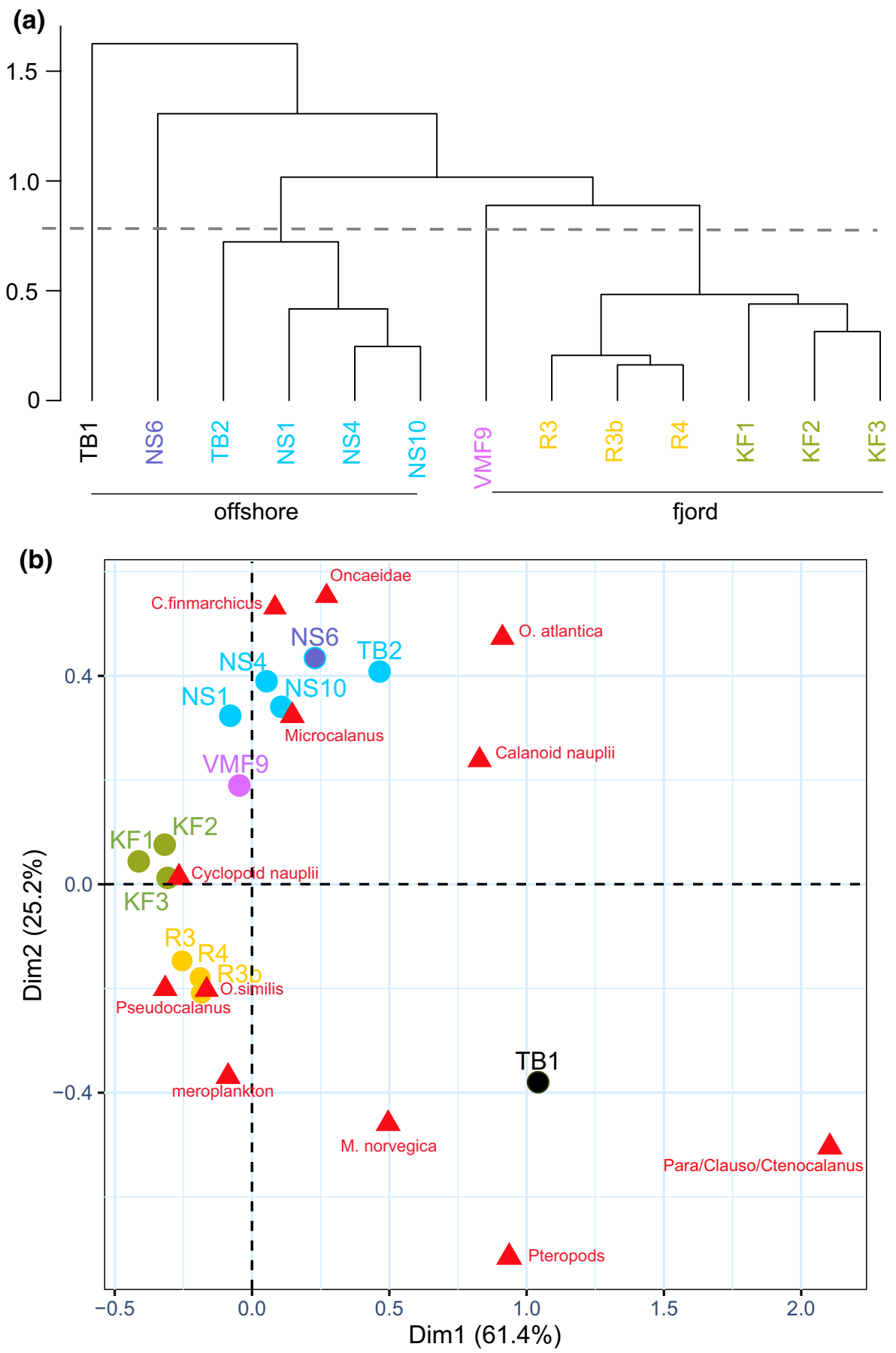

abundances, resulting in a female:male ratio of 1.8 (dispersion interval $=[0.5,5.0], n=8)$.

\section{Discussion}

Small taxa (i.e., small copepods, copepod nauplii, and meroplankton) constitute a large part of the mesozooplankton present in the Barents Sea and Svalbard fjords during the polar night of the Arctic winter, as is also the case during other seasons (Basedow et al. 2018; Svensen et al. 2019). Based on copepodid stage composition, we identified three main population structures among the seven dominant copepod species present: (1) populations dominated by near mature stages, specifically copepodid stages CIV and CV (Calanus spp.), (2) populations dominated by adults ( $M$. norvegica), and (3) populations with all copepodid stages present ( $M$. longa, Pseudocalanus spp., Microcalanus spp., and $O$. similis). In the latter case, the relative contributions of the different stages varied from a high proportion of adults (M. longa) 
to a dominance of young copepodids (CI-III) (Microcalanus spp.). The three population structures indicate that different overwintering strategies are adopted by the copepod species.

\section{Three strategies adopted by copepods during winter}

\section{Strategy 1: overwintering as late copepodid stages}

Calanus finmarchicus and C. glacialis are typically dormant at depth during winter, with CIV and CV as the main diapause stages (Niehoff 2000; Falk-Petersen et al. 2009). Calanus glacialis initiates molting to adults in winter and mating has been observed during the polar night (Daase et al. 2018), whereas these occur later in C. finmarchicus. The female:male ratios observed in our study in these two Calanus species confirm these differences.

Calanus spp. are known to remain at depth during winter and then ascend to surface water prior to the spring bloom (Hirche and Kosobokova 2011), but Calanus spp. may be present in surface waters in January (Pedersen et al. 1995; Daase et al. 2014, 2018; Basedow et al. 2018; Berge et al. 2020). We observed a similar situation at our northern stations (both shelf stations and fjords), where the majority of the Calanus spp. populations resided in surface waters, but not for the southern offshore stations and at Bellsund.

Individual copepods may not initiate diapause if their lipid reserves are insufficient for them to survive the winter (Pedersen et al. 1995; Maps et al. 2011; Hobbs et al. 2020). Concentrations of Chl $a$ and POC registered at the stations south or north of Bellsund gave no clear indications that there were differences in food availability. However, estimates of annual primary production are higher for the southern stations than further north (Reigstad et al. 2011). It is therefore possible that pre-winter feeding by copepods at the southern stations was higher than those further north, allowing more of them to enter diapause. Hobbs et al. (2020) suggested that availability of winter prey (i.e., microzooplankton) allows Calanus spp. to be flexible in their overwintering strategies. Calanus spp. are not strictly herbivorous, also feeding on microzooplankton, copepod eggs, and nauplii (Ohman and Runge 1994; Bonnet et al. 2004; Basedow and Tande 2006). The copepod nauplii biomass observed in our study may represent a valuable food source for Calanus spp. during winter, enabling them to fulfill metabolic demands.

Calanus spp. initiate molting at the end of the winter after hibernation (Falk-Pedersen et al. 2009). It is unclear why the non-hibernating copepods do not initiate their molting earlier. One reason could be that although visual predation might be reduced during the polar night, light intensities near the surface may still allow visual predation by some species, such as fish (Cohen et al. 2015; Langbehn and Varpe 2017). Adult Calanus spp. are common prey for visual predators because of their large size (Dahl et al. 2003; FalkPetersen et al. 2009). Calanus spp. CIV-CV are smaller than adults but are large enough to store lipid reserves so overwintering as $\mathrm{CIV}-\mathrm{CV}$ might increase chances of survival.

\section{Strategy 2: overwintering as an adult}

Microsetella norvegica, a pelagic harpacticoid copepod, was a member of the zooplankton communities ubiquitously recorded in our study. A dearth of young copepodids and dominance of adults in the $M$. norvegica populations suggests that recruitment of copepodids probably does not occur during winter. Previous studies in the Arctic and sub-Arctic have failed to register young copepodids during winter (Arendt et al. 2013; Svensen et al. 2018).

Observational evidence (Uye et al. 2002; Arendt et al. 2013; Svensen et al. 2018) indicates that female M. norvegica carry eggs shortly after the start of the spring bloom and last until late summer. Females may not lay eggs during winter, as no egg clutches have been observed during the winter from temperate to polar environments (Uye et al. 2002; Arendt et al. 2013), and egg hatching rates and egg hatching success are low at low temperatures (Barth-Jensen et al. 2020). Spending the winter as an adult would allow any energy surplus to be used for initiating reproduction in spring. In the case of large species like $C$. glacialis, females can use energy reserves to generate viable eggs, i.e., capital breeding (Daase et al. 2013; Sainmont et al. 2014). The small body volume of $M$. norvegica is not suited for accumulation of large lipid stores. Microsetella norvegica associates with particulate matter aggregates throughout the year (Koski et al. 2005), and could feed during winter to meet energy demands. However, decreases in female body carbon and nitrogen from November to their minimum in March (Svensen et al. 2018) indicate a lack of energy accumulation during winter, so it is unlikely that endogenous energy reserves could be used to fuel egg production in early spring. Therefore, $M$. norvegica is likely dependent on the spring bloom to fuel its reproduction.

\section{Strategy 3: mix of age classes during winter}

Four species were represented by all copepodid stages in January, but there were differences between the species as to which stages dominated: Microcalanus spp. populations consisted mainly of young copepodids (CI-CIII), $O$. similis, and Pseudocalanus spp. were mostly present as $\mathrm{CIV}$ and $\mathrm{CV}$, and $M$. longa as adults. A high abundance of young copepodids CI-CIII in Microcalanus spp. during winter has been previously observed in Kongsfjorden, Svalbard (Lischka and Hagen 2016), and in the Antarctic (Schnack-Schiel and Mizdalski 1994). In comparison to the $>50 \%$ of CI-CIII found during the polar night, CI-CIII 
represented only up to $50 \%$ in the spring and up to $40 \%$ in the summer (Lischka and Hagen 2016). As CI was the most common stage, Microcalanus spp. populations recruit copepodids during the winter, and it is likely that they are reproducing (Lischka and Hagen 2016). Given the high proportions of young copepodids, winter may be an important season for recruitment of Microcalanus spp.

Late spring and early autumn have been identified as the main reproductive periods of $O$. similis and Pseudocalanus spp. (Lischka and Hagen 2005, 2016; Dvoretsky and Dvoretsky 2009a), while for M. longa the main spawning period is late summer and autumn (Ussing 1938). Similar to Lischka and Hagen $(2005,2016)$, we observed only a few CI of $O$. similis, Pseudocalanus spp., and M. longa during winter while CII and CIII were more abundant. This indicates that recruitment of $\mathrm{CI}$ is probably low during winter, and that winter is mainly used for growth and development of the young copepodids (Ussing 1938; Lischka and Hagen 2005).

At low temperatures, development from eggs to CI may take months in polar waters: $O$. similis egg development to the time of hatch can take weeks (Barth-Jensen et al. 2020 ) and the growth of nauplii is isochronal (Sabatini and Kiørboe 1994). Based on equations developed by Eiane and Ohman (2004), we estimate 114 days are needed for development of $O$. similis from egg to $\mathrm{CI}$ at $2{ }^{\circ} \mathrm{C}$. Thus, eggs laid in September would likely have reached the CI stage by January and we suggest that the CI-CIII found in January likely come from eggs produced during the previous autumn. Based on the high abundance of CI-CIII in our study, we suggest that egg fitness, defined as the likelihood of an egg producing an individual that contributes to future generations (Varpe et al. 2007) is quite high for eggs produced during the autumn. This suggestion is supported by the abundances of the different stages of $O$. similis in Kongsfjord, Svalbard, as reported by Lischka and Hagen (2005): the early autumn generation was characterized by low nauplii abundance (data not shown) but high abundance of CI-CIII in November (140,000 ind. $\left.\mathrm{m}^{-2}\right)$ and February (16 500 ind. $\mathrm{m}^{-2}$ ), while the early summer generation was characterized by a high nauplii concentration $(31,000$ ind. $\mathrm{m}^{-2}$ ) which developed into a relative low concentration of CI-CIII $\left(24,000\right.$ ind. $\left.\mathrm{m}^{-2}\right)$ in July.

Overwintering in the upper water column as copepodids in Microcalanus spp., O. similis, Pseudocalanus spp., and $M$. longa may be a survival strategy to reduce predation pressure. Predators, such as large copepods (Sell et al. 2001; Bonnet et al. 2004), chaetognaths or fish larvae (Falkenhaug 1991; Swalethorp et al. 2014; Mitsuzawa et al. 2017; Grønkjær et al. 2018) that prey on nauplii and small copepodids may be present in surface waters during winter, but at lower abundances than in other seasons (Daase et al. 2013; Grigor et al. 2014, 2017). Therefore, the impact of the predators' feeding activity is likely reduced, leading to lower copepod mortality.

\section{Copepod nauplii and winter production of copepods}

Low temperatures and low food availability in winter impact copepods production by lowering their reproductive output, as the clutch size increase with temperature and prey availability (e.g., Dvoretsky and Dvoretsky 2009b; Head et al. 2013; Barth-Jensen et al. 2020). Therefore, the copepods' winter production can be assumed to be low. Nevertheless, the abundances of calanoid and cyclopoid nauplii during winter cannot be neglected (e.g., Digby 1954; Lischka and Hagen 2005; Grenvald et al. 2016; this study), although spring and summer abundances can be thirty times higher (Lischka and Hagen 2016). We did not classify nauplii according to stage, but they were probably a mix of young (i.e., newly hatched from eggs) and later stages resulting from an earlier egg production event. Therefore, the nauplii were probably of those species whose populations also had young copepodids CI-CIII and ovigerous females. According to the different population structures observed here, the species that likely contributed most to the nauplii population are those with a mix of age classes in their populations (i.e., strategy 3). The low abundances of harpacticoid nauplii corroborate that $M$. norvegica likeky do not reproduce during winter. For Calanus spp., females can lay eggs prior to the spring bloom (Sainmont et al. 2014), but the low abundance of females makes them unlikely as major contributors to the observed calanoid nauplii pool.

Winter production of $O$. similis and Pseudocalanus spp. in the Arctic has been documented (Digby 1954; Lischka and Hagen 2005) and our finding of egg-carrying females of $O$. similis and Pseudocalanus spp. in January corroborates this. Winter reproduction in the Arctic is at its minimum, with $\leq 10 \%$ of the $O$. similis females bearing eggs, compared to summer and autumn where up to $50 \%$ of the females can be ovigerous (Dvoretsky and Dvoretsky 2009a, 2009b; Apollonio 2013). This is probably due to food shortage limiting the reproduction of income breeders such as $O$. similis and Pseudocalanus spp. during winter (Varpe et al. 2009). Although a low winter egg production by $O$. similis and Pseudocalanus spp. would supply a few newly hatched nauplii to the nauplii pool, it can not explain the high abundance of nauplii observed in our study.

Lischka and Hagen (2005) observed high concentrations of copepod eggs $\left(33,200 \mathrm{~m}^{-2}\right)$ within the size range of $O$. similis eggs, in Kongsfjorden in November. If we assume that 114 days are needed to development from egg to CI at $2{ }^{\circ} \mathrm{C}$ (extrapolated from Eiane and Ohman 2004), most nauplii observed in January could have originated from eggs produced in late autumn. Nauplii of $O$. similis are 111 to $279 \mu \mathrm{m}$ long (Takahashi and Uchiyama 2007), which 
matches the most common size of nauplii in our study, so older naupliar stages of $O$. similis may have been the most important contributors to the cyclopoid nauplii pool. The observation that late naupliar stages were most abundant in Greenland fjords in February (Zamora-Terol et al. 2013) supports our interpretation. However, it is unlikely that all cyclopoid nauplii were $O$. similis. Triconia borealis was quite common and we observed mating in this species. Triconia borealis seems to reproduce year-round, and large proportions of young copepodids are sometimes observed during winter (Nishibe and Ikeda 2007; Lischka and Hagen 2016). The cyclopoid nauplii we collected may have included T. borealis nauplii. Pseudocalanus spp. nauplii are between 176 and $440 \mu \mathrm{m}$ (Ogilvie 1953). Large nauplii were rare in our samples, so Pseudocalanus spp. probably contributed little to the calanoid nauplii community.

Metridia longa are not mature during winter (Tande and Grønvik 1983), but Microcalanus spp. are ripe during winter (Norrbin 1991; Kosobokova and Hirche 2016), and Microcalanus nauplii measure 80 to $210 \mu \mathrm{m}$ (Ogilvie 1953). Using (1938) visually recorded Microcalanus spp. nauplii in February in East Greenlandic fjords. The high abundances of small calanoid nauplii, particularly at offshore stations where Microcalanus spp. were abundant, suggest that Microcalanus spp. may have been a major contributor to the calanoid nauplii pool at some of our sampling stations. Other copepod species may have contributed to the nauplii pool, and future studies should include molecular identification of the nauplii to identify their species (Fujioka et al. 2015). Nauplii could have hatched from dormant eggs, the development of which was slow under winter conditions (Mauchline 1998), but it is unlikely that the hatching of resting eggs would have been triggered during winter.

\section{Meroplankton}

Presence of meroplankton in our samples open the possibility of some reproductive activity in benthic species during winter. Meroplankton from various taxa have been reported to be present in Arctic and sub-Arctic fjords during the polar night, although at lower abundances than in spring or summer (Hannerz 1956; Blake 1969; Kuklinski et al. 2013; Stübner et al. 2016; Michelsen et al. 2017; Weydmann-Zwolicka et al. 2021). We recorded eight times more polychaete larvae and a similar or higher abundance of bivalve veliger in Rijpfjorden and on the shelf north of Svalbard than previously reported in other Svalbard fjords during the polar night (Kuklinski et al. 2013; Weydmann-Zwolicka et al. 2021), making these taxa the dominant component of the meroplankton community in Rijpfjorden. In contrast, meroplankton was dominated by bryozoans, gastropods, and eggs and embryos of a range of other taxa in Isfjorden and Adventfjorden, Svalbard, although bivalve veliger and polychaete larvae were also present (Stübner et al. 2016; WeydmannZwolicka et al. 2021). The benthic communities were mainly composed of bivalves and polychaetes during the polar night in Rijpfjorden and Adventjorden, but the most abundant species within these taxa varied (Pawłowska et al. 2011; Morata et al. 2015). The different benthic communities in each fjord likely explain the difference in the meroplankton species composition. The diversity of meroplanktonic communities during winter indicates that winter reproduction may occur in various species among a wide range of benthic taxa. Some species have larvae with substantial energy reserves, i.e., lecithotrophic larvae, which may have been produced before winter, but planktotrophic larvae are also found during winter (Michelsen et al. 2017; Weydmann-Zwolicka et al. 2021). Reproduction during winter may be a strategy to ensure survival of early life stages in a period when both predation pressure and inter-specific competition with other larvae are low, even though food availability may be low and the risk of death by starvation may be quite high.

\section{Conclusion}

We studied the zooplankton communities of the western Barents Sea and fjords around Svalbard in January during the Arctic polar night and focused on the age structure of the seven most abundant small and large copepod species. Communities were dominated by copepod nauplii and small copepods, and depicted active communities driven by reproductive activity and winter development of copepods and meroplankton. Three overwintering strategies were observed. Calanus spp. spends winter as immature latestage copepodids. Microsetella norvegica overwinters as adults, which could be advantageous as a preparation for egg production in spring. Microcalanus spp. were mainly CI-CIII, suggesting recruitment, and Microcalanus is probably a contributor to the naupliar pool present during winter. Pseudocalanus spp. and $O$. similis reproduce during winter, although egg production rates appear to be low. For these two species, winter is likely mainly used for growth and development. Metridia longa probably adopts a similar strategy. Taking the above into account, we propose that the winter nauplii assemblage mostly consists of older stages of O. similis, Pseudocalanus spp., and possibly M. longa, and younger and older naupliar stages of Microcalanus spp. and possibly $T$. borealis.

The presence of meroplankton during winter suggests that some benthic species (mainly polychaetes and bivalves) may be reproducing during this time. Although winter is a season of decreased activity for many zooplankton species, some may rely on the reduced predation pressure or the food produced during previous season to boost recruitment leading to high abundances of larval and young stages in winter: 
nauplii, young copepodids and planktonic larvae. Our study highlights winter as being more than a resting period for small copepods, and contributes to strengthen the perception of a non-dormant Arctic winter.

Supplementary Information The online version contains supplementary material available at https://doi.org/10.1007/s00300-022-03025-4.

Acknowledgements We thank the crew of R/V Helmer Hanssen for their help during the field work, the ARCTOS network for financing the PNC17 cruise, and all the cruise participants for an enriching and enjoyable cruise. We would like extend our gratitude to Peter Glad for his help during the cruise, notably with the filtration of water samples. We extend our thanks to Marja Koski and two anonymous reviewers who helped improve this manuscript. We thank Malcolm Jobling for his mentoring during the writing process and for the English proofreading of the text. This study is a contribution to the ARCTOS research network (arctos.uit.no).

Author contributions $\mathrm{CBJ}$ and CS conceived and designed the study. $\mathrm{CBJ}$ and $\mathrm{MD}$ conducted the field sampling. CBJ, MO, and SK did the lab analyses. CBJ and MD made the figures. CBJ wrote the manuscript. All authors commented, reviewed, and approved the manuscript.

Funding Open Access funding provided by UiT The Arctic University of Norway. UiT funded the PhD grant of CBJ, and the ARCTOS network funded parts of the cruise. The fieldwork was funded by the Norwegian Research Council [Arctic ABC (244319)]. MD received additional funding through NRC project Deep Impact (300333) and was supported by Troms $\varnothing$ Forskningsstiftelse (project Arctic ABC-East).

Data availability Abundance data for all species are available in an online repository https://www.gbif.org/dataset/76ef1883-c32a-49bba36c-2752af1b4e95. In this manuscript, it is referred as "Barth-Jensen et al. $2022 "$.

\section{Declarations}

Conflict of interest The authors declare that they have no conflict of interest.

Open Access This article is licensed under a Creative Commons Attribution 4.0 International License, which permits use, sharing, adaptation, distribution and reproduction in any medium or format, as long as you give appropriate credit to the original author(s) and the source, provide a link to the Creative Commons licence, and indicate if changes were made. The images or other third party material in this article are included in the article's Creative Commons licence, unless indicated otherwise in a credit line to the material. If material is not included in the article's Creative Commons licence and your intended use is not permitted by statutory regulation or exceeds the permitted use, you will need to obtain permission directly from the copyright holder. To view a copy of this licence, visit http://creativecommons.org/licenses/by/4.0/.

\section{References}

Apollonio S (2013) Temporal patterns of Arctic and subarctic zooplankton community composition in Jones Sound, Canadian Arctic Archipelago (1961-62, 1963). Arctic 66:463-469. https://doi. org/10.14430/arctic4333
Arendt KE, Juul-Pedersen T, Mortensen J, Blicher ME, Rysgaard S (2013) A 5-year study of seasonal patterns in mesozooplankton community structure in a sub-Arctic fjord reveals dominance of Microsetella norvegica (Crustacea, Copepoda). J Plankton Res 35:105-120. https://doi.org/10.1093/plankt/fbs087

Atkinson A (1998) Life cycle strategies of epipelagic copepods in the Southern Ocean. J Mar Syst 15:289-311. https://doi.org/10.1016/ S0924-7963(97)00081-X

Balazy K, Trudnowska E, Wichorowski M, Błachowiak-Samołyk K (2018) Large versus small zooplankton in relation to temperature in the Arctic shelf region. Polar Res 37:1427409. https://doi.org/ 10.1080/17518369.2018.1427409

Barth-Jensen C, Koski M, Varpe Ø, Glad P, Wangensteen OS, Præbel K, Svensen C (2020) Temperature-dependent egg production and egg hatching rates of small egg-carrying and broadcastspawning copepods Oithona similis, Microsetella norvegica and Microcalanus pusillus. J Plankton Res 42:564-580. https:// doi.org/10.1093/plankt/fbaa039

Barth-Jensen C, Daase M, Ormańczyk M, Kwaśniewski S, Varpe $\varnothing$, Svensen C (2022) Abundance of zooplankton during the polar night (cruise in January 2017) at 13 stations using a 64ummesh Multinet. UiT The Arctic University of Norway. Metadata dataset https://doi.org/10.15468/kebuss

Basedow SL, Tande KS (2006) Cannibalism by female Calanus finmarchicus on naupliar stages. Mar Ecol Prog Ser 327:247-255. https://doi.org/10.3354/meps327247

Basedow SL, Sundfjord A, Von Appen W-J, Halvorsen E, Kwasniewski S, Reigstad M (2018) Seasonal variation in transport of zooplankton into the Arctic Basin through the Atlantic gateway, Fram Strait. Front Mar Sci 5:194. https://doi.org/10.3389/ fmars.2018.00194

Båtnes AS, Miljeteig C, Berge J, Greenacre M, Johnsen G (2015) Quantifying the light sensitivity of Calanus spp. during the polar night: potential for orchestrated migrations conducted by ambient light from the sun, moon, or aurora borealis? Polar Biol 38:51-65. https://doi.org/10.1007/s00300-013-1415-4

Benedetti F (2015) Mediterranean copepods' functional traits. Supplement to: Benedetti, F., Gasparini, S. and Ayata, S.-D. (2016): Identifying copepod functional groups from species functional traits. J Plankton Res 38:159-166

Berge J, Cottier F, Last K et al (2009) Diel vertical migration of Arctic zooplankton during the polar night. Biol Lett 5:69-72. https://doi.org/10.1098/rsbl.2008.0484

Berge J, Daase M, Renaud PE et al (2015a) Unexpected levels of biological activity during the polar night offer new perspectives on a warming Arctic. Curr Biol 25:2555-2561. https:// doi.org/10.1016/j.cub.2015.08.024

Berge J, Renaud PE, Darnis G et al (2015b) In the dark: a review of ecosystem processes during the Arctic polar night. Prog Oceanogr 139:258-271. https://doi.org/10.1016/j.pocean.2015. 08.005

Berge J, Daase M, Hobbs L, Falk-Petersen S, Darnis G, Søreide JE (2020) Chapter 13: Zooplankton in the Polar Night. In: Berge J, Johnsen G, Cohen JH (eds) POLAR NIGHT marine ecology: life and light in the dead of night. Advances in polar ecology, vol 4. Springer, Cham, pp 113-160

Blake JA (1969) Reproduction and larval development of Polydora from Northern New England (Polychaeta: spionidae). Ophelia 7:1-63. https://doi.org/10.1080/00785326.1969.10419288

Bonnet D, Titelman J, Harris R (2004) Calanus the cannibal. J Plankton Res 26:937-948. https://doi.org/10.1093/plankt/fbh087

Calbet A, Saiz E (2005) The ciliate-copepod link in marine ecosystems. Aquat Microb Ecol 38:157-167. https://doi.org/10.3354/ ame 038157

Castellani C, Irigoien X, Harris R, Holliday N (2007) Regional and temporal variation of Oithona spp. biomass, stage structure and 
productivity in the Irminger Sea, North Atlantic. J Plankton Res 29:1051-1070. https://doi.org/10.1093/plankt/fbm079

Choquet M, Kosobokova K, Kwaśniewski S et al (2018) Can morphology reliably distinguish between the copepods Calanus finmarchicus and C. glacialis, or is DNA the only way? Limnol Oceanogr: Meth 16:237-252. https://doi.org/10.1002/lom3.10240

Cohen JH, Berge J, Moline MA et al (2015) Is ambient light during the high Arctic polar night sufficient to act as a visual cue for zooplankton? PLoS ONE 10:e0126247. https://doi.org/10.1371/ journal.pone.0126247

Cohen JH, Berge J, Moline MA, Johnsen G, Zolich AP (2020) Chapter 3: light in the polar night. In: Berge J, Johnsen G, Cohen JH (eds) POLAR NIGHT marine ecology: life and light in the dead of night. Advances in polar ecology, vol 4. Springer, Cham, pp $37-66$

Conover R (1988) Comparative life histories in the genera Calanus and Neocalanus in high latitudes of the northern hemisphere. Hydrobiologia 167-168:127-142. https://doi.org/10.1007/BF00026299

Cottier F, Tverberg V, Inall M, Svendsen H, Nilsen F, Griffiths C (2005) Water mass modification in an Arctic fjord through cross-shelf exchange: The seasonal hydrography of Kongsfjorden, Svalbard. J Geophys Res 110:C12005. https://doi.org/10.1029/2004JC0027 57

Daase M, Falk-Petersen S, Varpe $\varnothing$ et al (2013) Timing of reproductive events in the marine copepod Calanus glacialis: a pan-Arctic perspective. Can J Fish Aquat Sci 70:871-884. https://doi.org/ 10.1139/cjfas-2012-0401

Daase M, Varpe Ø, Falk-Petersen S (2014) Non-consumptive mortality in copepods: occurrence of Calanus spp. carcasses in the Arctic Ocean during winter. J Plankton Res 36:129-144. https://doi.org/ 10.1093/plankt/fbt079

Daase M, Kosobokova K, Last KS, Cohen JH, Choquet M, Hatlebakk MKV, Søreide J (2018) New insights into the biology of Calanus spp. (Copepoda) males in the Arctic. Mar Ecol Prog Ser 607:53-69. https://doi.org/10.3354/meps12788

Dahl TM, Falk-Petersen S, Gabrielsen GW, Sargent JR, Hop H, Millar RM (2003) Lipids and stable isotopes in common eider, blacklegged kittiwake and northern fulmar: a trophic study from an Arctic fjord. Mar Ecol Prog Ser 256:257-269. https://doi.org/10. 3354/meps 256257

Darnis G, Robert D, Pomerleau C et al (2012) Current state and trends in Canadian Arctic marine ecosystems: II. Heterotrophic food web, pelagic-benthic coupling, and biodiversity. Clim Change 115:179-205. https://doi.org/10.1007/s10584-012-0483-8

Darnis G, Hobbs L, Geoffroy M et al (2017) From polar night to midnight sun: diel vertical migration, metabolism and biogeochemical role of zooplankton in a high Arctic fjord (Kongsfjorden, Svalbard). Limnol Oceanogr 62:1586-1605. https://doi.org/10. 1002/lno.10519

Digby PSB (1954) The biology of the marine planktonic copepods of Scoresby Sound, East Greenland. J Anim Ecol 23:298-338. https://doi.org/10.2307/1984

Dvoretsky VG, Dvoretsky AG (2009a) Life cycle of Oithona similis (Copepoda: Cyclopoida) in Kola Bay (Barents Sea). Mar Biol 156:1433-1446. https://doi.org/10.1007/s00227-009-1183-4

Dvoretsky VG, Dvoretsky AG (2009b) Spatial variations in reproductive characteristics of the small copepod Oithona similis in the Barents Sea. Mar Ecol Prog Ser 386:133-146. https://doi.org/ 10.3354/meps08085

Dvoretsky VG, Dvoretsky AG (2014) The biodiversity of zooplankton communities of the west Arctic Seas. Russ J Mar Biol 40:95-99. https://doi.org/10.1134/S1063074014020035

Dvoretsky VG, Dvoretsky AG (2015) Early winter mesozooplankton of the coastal south-eastern Barents Sea. Estuar Coast Shelf Sci 152:116-123. https://doi.org/10.1016/j.ecss.2014.11.016
Dvoretsky VG, Dvoretsky AG (2015b) Zooplankton in the areas of polynya formation in the seas of the Arctic Ocean. Russ J Mar Biol 41:223-237. https://doi.org/10.1134/S1063074015040070

Eiane K, Ohman MD (2004) Stage-specific mortality of Calanus finmarchicus, Pseudocalanus elongatus and Oithona similis on Fladen Ground, North Sea, during a spring bloom. Mar Ecol Prog Ser 268:183-193. https://doi.org/10.3354/meps268183

Falkenhaug T (1991) Prey composition and feeding rate of Sagitta elegans var. arctica (chaetognatha) in the Barents Sea in early summer. Polar Res 10:487-506. https://doi.org/10.1111/j.17518369.1991.tb00668.x

Falk-Petersen S, Mayzaud P, Kattner G, Sargent JR (2009) Lipids and life strategy of Arctic Calanus. Mar Biol Res 5:18-39. https:// doi.org/10.1080/17451000802512267

Fujioka HA, Machida RJ, Tsuda A (2015) Early life history of Neocalanus plumchrus (Calanoida: Copepoda) in the western subarctic Pacific. Prog Oceanogr 137:196-208. https://doi.org/10.1016/j. pocean.2015.06.004

Gabrielsen TM, Merkel B, Søreide JE et al (2012) Potential misidentifications of two climate indicator species of the marine arctic ecosystem: Calanus glacialis and C. finmarchicus. Polar Biol 35:1621-1628. https://doi.org/10.1007/s00300-012-1202-7

Greenacre M (2016) Data reporting and visualization in ecology. Polar Biol 39:2189-2205. https://doi.org/10.1007/s00300-016-2047-2

Grenvald JC, Callesen TA, Daase M et al (2016) Plankton community composition and vertical migration during polar night in Kongsfjorden. Polar Biol 39:1879-1895. https://doi.org/10.1007/ s00300-016-2015-x

Grigor JJ, Søreide JE, Varpe Ø (2014) Seasonal ecology and lifehistory strategy of the high-latitude predatory zooplankter Parasagitta elegans. Mar Ecol Prog Ser 499:77-88. https://doi.org/ $10.3354 /$ meps 10676

Grigor JJ, Schmid MS, Fortier L (2017) Growth and reproduction of the chaetognaths Eukrohnia hamata and Parasagitta elegans in the Canadian Arctic Ocean: capital breeding versus income breeding. J Plankton Res 39:910-929. https://doi.org/10.1093/ plankt/fbx045

Grønkjær P, Nielsen KV, Zoccarato G, Meire L, Rysgaard S, Hedeholm RB (2018) Feeding ecology of capelin (Mallotus villosus) in a fjord impacted by glacial meltwater (Godthåbsfjord, Greenland). Polar Biol 42:81-98. https://doi.org/10.1007/s00300-018-2400-8

Grønvik S, Hopkins CCE (1984) Ecological investigations of the zooplankton community of Balsfjorden, northern Norway: generation cycle, seasonal vertical distribution, and seasonal variations in body weight and carbon and nitrogen content of the copepod Metridia longa (Lubbock). J Exp Mar Biol Ecol 80:93-107. https://doi.org/10.1016/0022-0981(84)90096-0

Hannerz L (1956) Larval development of the Polychaete families Spionidae Sars, Disomidae Mesnil, and Poecilochaetidae n. fam. in the Gullmar Fjord (Sweden). Zool Idr Upps 31:1-204

Head EJH, Harris LR, Ringuette M, Campbell RW (2013) Characteristics of egg production of the planktonic copepod, Calanus finmarchicus, in the Labrador Sea: 1997-2010. J Plankton Res 35:281-298. https://doi.org/10.1093/plankt/fbs097

Hirche HJ, Kosobokova KN (2011) Winter studies on zooplankton in Arctic seas: the Storfjord (Svalbard) and adjacent ice-covered Barents Sea. Mar Biol 158:2359-2376. https://doi.org/10.1007/ s00227-011-1740-5

Hobbs L, Banas NS, Cottier FR, Berge J, Daase M (2020) Eat or sleep: availability of winter prey explains mid-winter and spring activity in an Arctic Calanus population. Front Mar Sci. https://doi. org/10.3389/fmars.2020.541564

Koski M, Kiørboe T, Takahashi K (2005) Benthic life in the pelagic: aggregate encounter and degradation rates by pelagic harpacticoid copepods. Limnol Oceanogr 50:1254-1263. https://doi.org/ 10.4319/lo.2005.50.4.1254 
Koski M, Møller EF, Maar M, Visser AW (2007) The fate of discarded appendicularian houses: degradation by the copepod, Microsetella norvegica, and other agents. J Plankton Res 29:641-654. https://doi.org/10.1093/plankt/fbm046

Kosobokova KN, Hirche HJ (2016) A seasonal comparison of zooplankton communities in the Kara Sea-with special emphasis on overwintering traits. Estuar Coast Shelf Sci 175:146-156. https://doi.org/10.1016/j.ecss.2016.03.030

Kraft A, Berge J, Varpe $\varnothing$, Falk-Petersen S (2013) Feeding in Arctic darkness: mid-winter diet of the pelagic amphipods Themisto abyssorum and T. libellula. Mar Biol 160:241-248. https://doi. org/10.1007/s00227-012-2065-8

Kuklinski P, Berge J, McFadden L et al (2013) Seasonality of occurrence and recruitment of Arctic marine benthic invertebrate larvae in relation to environmental variables. Polar Biol 36:549560. https://doi.org/10.1007/s00300-012-1283-3

Kwasniewski S, Hop H, Falk-Petersen S, Pedersen G (2003) Distribution of Calanus species in Kongsfjorden, a glacial fjord in Svalbard. J Plankton Res 25:1-20. https://doi.org/10.1093/plankt/ 25.1.1

Langbehn TJ, Varpe $\varnothing$ (2017) Sea-ice loss boosts visual search: fish foraging and changing pelagic interactions in polar oceans. Glob Chang Biol 23:5318-5330. https://doi.org/10.1111/gcb.13797

Lischka S, Hagen W (2005) Life histories of the copepods Pseudocalanus minutus, P. acuspes (Calanoida) and Oithona similis (Cyclopoida) in the Arctic Kongsfjorden (Svalbard). Polar Biol 28:910-921. https://doi.org/10.1007/s00300-005-0017-1

Lischka S, Hagen W (2016) Seasonal dynamics of mesozooplankton in the Arctic Kongsfjord (Svalbard) during year-round observations from August 1998 to July 1999. Polar Biol 39:1859-1878. https://doi.org/10.1007/s00300-016-2005-z

Lotufo GR (1994) Cyclopina (Copepoda, Cyclopoida) from Brazilian sandy beaches. Zoolog Scr 23:147-159. https://doi.org/10. 1111/j.1463-6409.1994.tb00381.x

Madsen SD, Nielsen TG, Hansen BW (2008) Annual population development and production by small copepods in Disko Bay, western Greenland. Mar Biol 155:63-77. https://doi.org/10.1007/ s00227-008-1007-y

Maps F, Runge JA, Leising A, Pershing AJ, Record NR, Plourde S, Pierson JJ (2011) Modelling the timing and duration of dormancy in populations of Calanus finmarchicus from the Northwest Atlantic shelf. J Plankton Res 34:36-54. https://doi.org/10. 1093/plankt/fbr088

Mauchline J (1998) The biology of calanoid copepods. In: Blaxter JHS, Southward AJ, Tyler PA (eds) Advances in marine biology, vol 33. Academic Press, Oxford, pp 1-710

Mayor DJ, Gentleman WC, Anderson TR (2020) Ocean carbon sequestration: particle fragmentation by copepods as a significant unrecognised factor? BioEssays. https://doi.org/10.1002/bies. 202000149

Michelsen HK, Svensen C, Reigstad M, Nilssen EM, Pedersen T (2017) Seasonal dynamics of meroplankton in a high-latitude fjord. J Mar Syst 168:17-30. https://doi.org/10.1016/j.jmarsys. 2016.12.001

Mitsuzawa A, Miyamoto H, Ueda H (2017) Feeding selectivity of early-stage fish larvae on the nauplii and eggs of different copepod species. Plankton Benthos Res 12:115-122. https://doi.org/ $10.3800 /$ pbr. 12.115

Morata N, Michaud E, Włodarska-Kowalczuk M (2015) Impact of early food input on the Arctic benthos activities during the polar night. Polar Biol 38:99-114. https://doi.org/10.1007/ s00300-013-1414-5

Nichols JH, Thompson AB (1991) Mesh selection of copepodite and nauplius stages of four calanoid copepod species. J Plankton Res 13:661-671. https://doi.org/10.1093/plankt/13.3.661
Niehoff B (2000) Effect of starvation on the reproductive potential of Calanus finmarchicus. ICES J Mar Sci 57:1764-1772. https:// doi.org/10.1006/jmsc.2000.0971

Nielsen TG, Andersen CM (2002) Plankton community structure and production along a freshwater-influenced Norwegian fjord system. Mar Biol 141:707-724. https://doi.org/10.1007/ s00227-002-0868-8

Nishibe Y, Ikeda T (2007) Vertical distribution, population structure and life cycles of four oncaeid copepods in the Oyashio region, western subarctic Pacific. Mar Biol 150:609-625. https://doi.org/ 10.1007/s00227-006-0382-5

Norrbin MF (1991) Gonad maturation as an indication of seasonal cycles for several species of small copepods in the Barents Sea. Polar Res 10:421-432. https://doi.org/10.3402/polar.v10i2.6756

Ogilvie HS (1953) Zooplankton sheet. 50 Nauplii (I). Conseil international pour l'exploration de la mer, Copenhagen

Ohman MD, Runge JA (1994) Sustained fecundity when phytoplankton resources are in short supply: omnivory by Calanus finmarchicus in the Gulf of st. Lawrence. Limnol Oceanogr 39:21-36. https:// doi.org/10.4319/1o.1994.39.1.0021

Oksanen J, Blanchet FG, Friendly M et al (2019) Vegan: community ecology package

Ormańczyk MR, Głuchowska M, Olszewska A, Kwasniewski S (2017) Zooplankton structure in high latitude fjords with contrasting oceanography (Hornsund and Kongsfjorden, Spitsbergen). Oceanologia 59:508-524. https://doi.org/10.1016/j.oceano.2017.06. 003

Pawłowska J, Włodarska-Kowalczuk M, Zajączkowski M, Nygård H, Berge J (2011) Seasonal variability of meio- and macrobenthic standing stocks and diversity in an Arctic fjord (Adventfjorden, Spitsbergen). Polar Biol 34:833-845. https://doi.org/10.1007/ s00300-010-0940-7

Pedersen G, Tande K, Ottesen GO (1995) Why does a component of Calanus finmarchicus stay in the surface waters during the overwintering period in high latitudes? ICES J Mar Sci 52:523-531. https://doi.org/10.1016/1054-3139(95)80066-2

Razouls C, Desreumaux N, Kouwenberg J, de Bovée F (2005-2021) Biodiversity of Marine Planktonic Copepods (morphology, geographical distribution and biological data). Available at http:// copepodes.obs-banyuls.fr/en. Accessed 27 May 2021

Reigstad M, Carroll J, Slagstad D, Ellingsen I, Wassmann P (2011) Intra-regional comparison of productivity, carbon flux and ecosystem composition within the northern Barents Sea. Prog Oceanogr 90:33-46. https://doi.org/10.1016/j.pocean.2011.02. 005

Roura Á, Strugnell JM, Guerra Á, González ÁF, Richardson AJ (2018) Small copepods could channel missing carbon through metazoan predation. Ecol Evol 8:10868-10878. https://doi.org/10. 1002/ece3.4546

Sabatini M, Kiørboe T (1994) Egg production, growth and development of the cyclopoid copepod Oithona similis. J Plankton Res 16:1329-1351. https://doi.org/10.1093/plankt/16.10.1329

Sainmont J, Andersen K, Varpe Ø, Visser A (2014) Capital versus income breeding in a seasonal environment. Am Nat 184:466476. https://doi.org/10.1086/677926

Saito H, Kiørboe T (2001) Feeding rates in the chaetognath Sagitta elegans: effects of prey size, prey swimming behaviour and small-scale turbulence. J Plankton Res 23:1385-1398. https:// doi.org/10.1093/plankt/23.12.1385

Schnack-Schiel SB, Mizdalski E (1994) Seasonal variations in distribution and population structure of Microcalanus pygmaeus and Ctenocalanus citer (Copepoda: Calanoida) in the eastern Weddell Sea, Antarctica. Mar Biol 119:357-366. https://doi.org/10. 1007/BF00347532 
Sell AF, van Keuren D, Madin LP (2001) Predation by omnivorous copepods on early developmental stages of Calanus finmarchicus and Pseudocalanus spp. Limnol Oceanogr 46:953-959. https:// doi.org/10.4319/lo.2001.46.4.0953

Søreide JE, Falk-Petersen S, Hegseth EN, Hop H, Carroll ML, Hobson KA, Blachowiak-Samolyk K (2008) Seasonal feeding strategies of Calanus in the high-Arctic Svalbard region. Deep Sea Res, Part II 55:2225-2244. https://doi.org/10.1016/j.dsr2.2008.05.024

Strickland JDH, Parsons TR (1972) A practical handbook of seawater analysis, 2nd edn. Fisheries Research Board of Canada, Ottawa

Stübner EI, Søreide JE, Reigstad M, Marquardt M, BlachowiakSamolyk K (2016) Year-round meroplankton dynamics in highArctic Svalbard. J Plankton Res 38:522-536. https://doi.org/10. 1093/plankt/fbv124

Svensen C, Kiørboe T (2000) Remote prey detection in Oithona similis: hydromechanical versus chemical cues. J Plankton Res 22:11551166. https://doi.org/10.1093/plankt/22.6.1155

Svensen C, Antonsen MT, Reigstad M (2018) Small copepods matter: population dynamics of Microsetella norvegica in a high-latitude coastal ecosystem. J Plankton Res 40:446-457. https://doi.org/ 10.1093/plankt/fby019

Svensen C, Halvorsen E, Vernet M, Franzè G, Dmoch K, Lavrentyev PJ, Kwasniewski S (2019) Zooplankton communities associated with new and regenerated primary production in the Atlantic inflow North of Svalbard. Front Mar Sci 6:293. https://doi.org/ 10.3389/fmars.2019.00293

Swalethorp R, Kjellerup S, Malanski E, Munk P, Nielsen TG (2014) Feeding opportunities of larval and juvenile cod (Gadus morhua) in a Greenlandic fjord: temporal and spatial linkages between cod and their preferred prey. Mar Biol 161:2831-2846. https://doi. org/10.1007/s00227-014-2549-9

Takahashi T, Uchiyama I (2007) Morphology of the naupliar stages of some Oithona species (Copepoda: Cyclopoida) occurring in Toyama Bay, southern Japan Sea. Plankton Benthos Res 2:12. https://doi.org/10.3800/pbr.2.12

Tande KS, Grønvik S (1983) Ecological investigations on the zooplankton community of Balsfjorden, northern Norway: sex ratio and gonad maturation cycle in the copepod Metridia longa (Lubbock). J Exp Mar Biol Ecol 71:43-54. https://doi.org/10.1016/ 0022-0981(83)90103-X

Ussing HH (1938) The biology of some important plankton animals in the fjords of east Greenland. PhD thesis, København: C.A. Reitzel

Uye S-I, Aoto I, Onbé T (2002) Seasonal population dynamics and production of Microsetella norvegica, a widely distributed but little-studied marine planktonic harpacticoid copepod. J Plankton Res 24:143-153. https://doi.org/10.1093/plankt/24.2.143

Vader A, Marquardt M, Meshram AR, Gabrielsen TM (2015) Key Arctic phototrophs are widespread in the polar night. Polar Biol 38:13-21. https://doi.org/10.1007/s00300-014-1570-2

Varpe $\varnothing$ (2012) Fitness and phenology: annual routines and zooplankton adaptations to seasonal cycles. J Plankton Res 34:267-276. https://doi.org/10.1093/plankt/fbr108

Varpe Ø, Jørgensen C, Tarling GA, Fiksen Ø (2007) Early is better: seasonal egg fitness and timing of reproduction in a zooplankton life-history model. Oikos 116:1331-1342. https://doi.org/10. 1111/j.0030-1299.2007.15893.x

Varpe $\varnothing$, Jørgensen C, Tarling GA, Fiksen Ø (2009) The adaptive value of energy storage and capital breeding in seasonal environments. Oikos 118:363-370. https://doi.org/10.1111/j.1600-0706.2008. 17036.x

Wallace MI, Cottier FR, Berge J, Tarling GA, Griffiths C, Brierley AS (2010) Comparison of zooplankton vertical migration in an ice-free and a seasonally ice-covered Arctic fjord: an insight into the influence of sea ice cover on zooplankton behavior. Limnol Oceanogr 55:831-845. https://doi.org/10.4319/lo.2010.55.2. 0831

Webster CN, Varpe Ø, Falk-Petersen S, Berge J, Stübner E, Brierley AS (2015) Moonlit swimming: vertical distributions of macrozooplankton and nekton during the polar night. Polar Biol 38:75-85. https://doi.org/10.1007/s00300-013-1422-5

Weydmann-Zwolicka A, Balazy P, Kuklinski P, Søreide JE, Patuła W, Ronowicz M (2021) Meroplankton seasonal dynamics in the high Arctic fjord: comparison of different sampling methods. Prog Oceanogr. https://doi.org/10.1016/j.pocean.2020.102484

WoRMS Editorial Board (2021). World register of marine species. Available from http://www.marinespecies.org at VLIZ. Accessed 11 Jan 2021. https://doi.org/10.14284/170

Zamora-Terol S, Nielsen TG, Saiz E (2013) Plankton community structure and role of Oithona similis on the western coast of Greenland during the winter-spring transition. Mar Ecol Prog Ser 483:85-102. https://doi.org/10.3354/meps 10288

Publisher's Note Springer Nature remains neutral with regard to jurisdictional claims in published maps and institutional affiliations. 